\title{
Expression of Chemokines and Chemokine Receptors During Human Renal Transplant Rejection
}

\author{
Stephan Segerer, MD, Yan Cui, MD, Frank Eitner, MD, Tracy Goodpaster, BA, \\ Kelly L. Hudkins, MS, Matthias Mack, MD, Jean-Pierre Cartron, DSc, Yves Colin, PhD, \\ Detlef Schlondorff, MD, and Charles E. Alpers, MD
}

\begin{abstract}
- Infiltration of renal allografts by leukocytes is a hallmark of acute transplant rejection. Chemokines attract leukocytes bearing specific chemokine receptors, and the specific leukocyte chemokine receptor phenotype is associated with types of immune responses, ie, T helper subtype 1 (Th1; CXC chemokine receptor 3 [CXCR3], CC chemokine receptor 5 [CCR5]) versus Th2 (CCR3, CCR4, CCR8). We studied the expression of the chemokine monocyte chemoattractant protein-1 and the chemokine receptors CCR2B and CXCR4 messenger RNA (mRNA) by in situ hybridization, as well as the chemokine receptors Duffy antigen receptor for chemokines (DARC) and CCR5 protein by immunohistochemistry in renal biopsy specimens with acute cellular rejection $(n=12)$ and acute vascular rejection $(n=8)$, transplant nephrectomy specimens $(n=6)$, and normal areas of tumor nephrectomy specimens $(n=5)$. CC chemokines and CC chemokine receptor mRNA expression were evaluated by ribonuclease protection assay in specimens from four transplant nephrectomies and one tumor nephrectomy. Upregulation of mRNAs for the chemokines, interferon-inducible protein-10 (IP-10); regulated on activation normal T-cell expressed and secreted; macrophage inflammatory protein-1 $\alpha$ (MIP-1 $\alpha$ ); MIP-1 $\beta$; and lymphotactin, as well as the chemokine receptors, CCR2 and CCR5, were documented during allograft rejection. CCR1 mRNA was detectable in both allografts and controls, but CCR3 and CCR8 were absent. The number of CXCR4, CCR5, and CCR2B mRNAs expressing leukocytes and DARC-positive vessels increased during rejection episodes. CXCR4 mRNA was the most widely expressed. Leukocytes in diffuse interstitial infiltrates were mainly CCR5 positive, but in areas in which leukocytes formed nodular aggregates of infiltrating cells, the number of CCR5-positive cells was low. Instead, leukocytes in these nodular aggregates mainly expressed CXCR4. DARC was expressed on peritubular capillaries, where it was upregulated in areas of interstitial infiltration. Induction of chemokines during renal allograft rejection is accompanied by infiltration of leukocytes bearing the respective chemokine receptors. The upregulation of the CXCR3 ligand IP-10, as well as CCR5 and its ligands, in the absence of CCR3 and CCR8 is indicative that renal allograft rejection is primarily the result of a Th1-type immune response.
\end{abstract}

(C) 2001 by the National Kidney Foundation, Inc.

INDEX WORDS: Chemokines; chemokine receptors; renal allograft rejection; Duffy antigen receptor for chemokines (DARC); immune response; T helper subtype 1 (Th1).

$\mathbf{R}$ EJECTION REMAINS a major obstacle to long-term survival of renal allografts. ${ }^{1,2}$ Acute rejection is manifested by leukocyte infiltration of different compartments of the transplanted kidney. ${ }^{3,4}$ The main types of infiltrating

From the University of Washington, Seattle, WA; Division of Nephrology, University of Aachen, Aachen, Germany; Medizinische Poliklinik, Klinikum der Universitaet, Munich, Germany; and INSERM U76, Institut National De La Tranfusion Sanguine, Paris, France.

Received June 22, 2000; accepted in revised form September 22, 2000.

Supported in part by grant no. DK 47659 for an O'Brien Kidney Research Center and grant no. HL63652 from the National Institutes of Health; and a grant from the Else Kröner-Fresenius-Stiftung, Bad Homburg von der Höhe, Germany.

Address reprint requests to Stephan Segerer, $M D$, University of Washington, Department of Pathology, C. Alpers Laboratory, Rm C415, Medical Center, Box 357470, 1959 NE Pacific St, Seattle, WA 98195. E-mail: ssegerer@u.washington.edu

(C) 2001 by the National Kidney Foundation, Inc. 0272-6386/01/3703-0008\$35.00/0

doi:10.1053/ajkd.2001.22076 cells are subsets of $\mathrm{T}$ cells and macrophages at different stages of activation. ${ }^{5-7}$ Distinct immune responses against different challenges are termed Thelper subtype 1 (Th1)-like or Th2-like according to the classes of Th cells involved. ${ }^{89}$ These subtypes of Th cells are characterized by the expression patterns of cytokines and chemokine receptors. ${ }^{8-11} \mathrm{~A}$ Th1 response resulting in activation of cytotoxic $\mathrm{T}$ cells and delayed-type hypersensitivity is believed to be important during transplant rejection. ${ }^{12,13}$

The role of chemokines, a family of small chemotactic cytokines, in various inflammatory responses has become apparent during the last decade. ${ }^{14-17}$ Several studies described the expression and potential role of chemokines and chemokine receptors during renal transplant rejection (reviewed in ${ }^{14}$ ). Data about chemokine-receptor expression during human transplant rejection are still scarce. ${ }^{18-21}$ In this study, we describe the morphological distribution of four chemokine receptors potentially involved in allograft infil- 
tration by $\mathrm{T}$ cells and macrophages. CXCR4positive cells, mainly $\mathrm{T}$ cells, have been shown to be involved in human renal allograft rejection. ${ }^{19}$ CCR5 is a receptor for the chemokines regulated on activation normal T-cell expressed and secreted (RANTES); macrophage inflammatory protein- $1 \alpha$ (MIP-1 $\alpha$ ); MIP-1 $\beta$; and monocyte chemoattractant protein-2 (MCP-2). Our previous studies imply that CCR5-positive cells might have an important role during interstitial infiltration. ${ }^{18,21}$ The distribution of cells expressing CCR2B (a receptor for MCP-1) during human renal transplant rejection is currently unknown. CXCR4, CCR5, and CCR2 are expressed on different subsets of T cells and monocytes/macrophages.

In this study, we show the upregulation of several CC chemokines and their corresponding receptors, consistent with a Th1-type reaction, within the allograft kidney. In addition, we describe localized patterns of leukocyte accumulation that correspond to distinct patterns of chemokine-receptor expression and are consistent with subpopulations of leukocytes being attracted by different chemokines. Finally, we show the expression of the promiscuous chemokine receptor, Duffy antigen receptor for chemokines (DARC), which shares ligands with CCR5 and CCR2 and is expressed on interstitial capillaries at sites where the extravasation of leukocytes might take place in part.

\section{METHODS}

\section{Renal Specimens}

Thirty-one renal specimens were examined. Included in the study were specimens from transplant nephrectomies $(\mathrm{n}=6)$ with acute cellular rejection only $(\mathrm{n}=2)$ and acute cellular and vascular rejection $(n=4)$. Renal transplant biopsy specimens included those with acute cellular rejection $(\mathrm{n}=12)$ and acute vascular rejection $(\mathrm{n}=8)$. Normal areas of tumor nephrectomy specimens served as controls $(\mathrm{n}=5)$. Renal biopsy specimens were from cases studied between 1995 and 1997 in the Department of Pathology, University of Washington (Seattle, WA). Biopsy specimens from patients with acute cellular or vascular rejection were included when sufficient material for multiple immunohistochemistry and in situ hybridization studies was available after routine diagnostic workup was completed. The nephrectomy specimens were collected during 1998 and 1999. Sufficient frozen material for RNA isolation was available in five nephrectomy cases, including a tumor nephrectomy $(\mathrm{n}=1)$ and renal allograft nephrectomies with acute cellular rejection $(n=2)$ and acute vascular rejection $(n=2)$. Approval of the University of Washington Internal Review Board for Human Subjects prescribed that no patient identifiers may be linked to studies involving nephrectomy or biopsy tissue; therefore, clinical data were not available for morphological correlations.

\section{RNA Isolation}

Total RNA was isolated applying the ToTALLY RNA total RNA isolation Kit (Ambion, Austin, TX) according to the instructions of the manufacturer. Frozen tissue was disrupted on dry ice and homogenized by a tissue homogenizer (Tissumizer SDT-1810; Teckmar, Cincinatti, OH) in $10 \mathrm{~mL}$ of denaturation solution per gram of tissue. After vigorous mixing with one volume of $\mathrm{Phenol} / \mathrm{CHCl}_{3}$ Solution \#1 (Ambion), the solution was incubated for 15 minutes on ice. Phases were separated by centrifugation. One tenth of the volume of $3 \mathrm{~mol} / \mathrm{L}$ of sodium acetate and one volume of $\mathrm{Phenol} / \mathrm{ChCl}_{3}$ Solution \#2 (Ambion) were added to the aqueous phase. After another incubation and centrifugation, RNA was recovered from the aqueous phase by isopropanol precipitation. Pellets were washed with $70 \%$ ethanol and resuspended in ribonuclease (RNase)-free water. RNA concentration was calculated according to absorbance in a spectrophotometer at a wavelength of $260 \mathrm{~nm}$.

\section{RNase Protection Assay}

The RiboQuant (Pharmingen, San Diego, CA) system was used for the comparison of chemokine and chemokine receptor messenger RNA (mRNA) expression by RNase protection assay (RPA). The templates for human CC chemokine receptors included CCR1-5 and CCR8 (hCR-5; Pharmingen), and the chemokine template included lymphotactin, RANTES, interferon-inducible protein-10 (IP-10), MIP-1 $\alpha$, MIP-1 $\beta$, MCP-1, interleukin-8, and I309 (a chemokine that binds to CCR8). The probe synthesis was performed in a total volume of $20 \mu \mathrm{L}$ containing $100 \mu \mathrm{Ci}$ of $\alpha$-phosphorus 32-labeled uridine triphosphate, $40 \mathrm{U}$ of RNasin, $10 \mathrm{mmol} / \mathrm{L}$ of dithiothreitol (DTT), $1 \times$ transcription buffer, guanidineadenine-cytosine-uracil (GACU) pool, $20 \mathrm{U}$ of T7 polymerase, and the RPA template set (Pharmingen). After 1 hour at $37^{\circ} \mathrm{C}$, the reaction was stopped by digestion of the template with $2 \mathrm{U}$ of RNase-free deoxyribonuclease for 15 minutes. Phenol extraction and ethanol precipitation were performed, and the pellet was washed with $90 \%$ ethanol. The air-dried pellet was dissolved in $50 \mu \mathrm{L}$ of hybridization buffer. RNA probes were dried in a vacuum evaporator centrifuge for 1 hour ( $15 \mu \mathrm{g}$ of RNA for chemokine receptors, $5 \mu \mathrm{g}$ of RNA for chemokines). Two microliters of probe diluted in hybridization buffer to $2.8 \mathrm{cpm} / \mu \mathrm{L}$ (chemokine receptors) or 3.1 counts per minute $(\mathrm{cpm}) / \mu \mathrm{L}$ (chemokines) were added to each RNA vial and incubated overnight at $56^{\circ} \mathrm{C}$. The probes were treated with RNase A+T1 mix (Pharmingen) at $30^{\circ} \mathrm{C}$ for 45 minutes, followed by a proteinase $\mathrm{K}$ digestion for 15 minutes at $37^{\circ} \mathrm{C}$. After another phenol extraction and ethanol precipitation, the probes were air dried, redissolved, and separated on a $5 \%$ acrylamide gel. The gel was dried on a gel drier and exposed to film for 2 to 7 days.

\section{Molecular Probes and In Situ Hybridization}

Specificity of the riboprobes for MCP-1, CXCR4, and CCR2B was previously described in detail. ${ }^{19,20,22,23}$ Complementary DNA for CCR2B was provided by Dr I.F. Charo (Gladstone Institute of Cardiovascular Disease, San Fran- 
cisco, CA). ${ }^{24}$ Complementary DNA for CXCR4 was obtained through the Acquired Immunodeficiency Syndrome (AIDS) Research and Reference Reagent Program (Division of AIDS, National Institute of Allergy and Infectious Diseases, National Institutes of Health, Bethesda, MD). It was originally provided by Dr N.R. Landau (Salk Institute for Biological Studies, La Jolla, CA). ${ }^{25}$

In situ hybridization was performed as previously described. ${ }^{19,20,23}$ In brief, after deparaffinization and rehydration, the tissue was digested in $5 \mu \mathrm{g} / \mathrm{mL}$ of proteinase $\mathrm{K}$ type XI (Sigma, St Louis, MO) for 30 minutes at $37^{\circ} \mathrm{C}$. Slides were rinsed, dehydrated, and air dried. After prehybridization in $100 \mu \mathrm{L}$ of buffer containing $0.3 \mathrm{~mol} / \mathrm{L}$ of $\mathrm{NaCl}, 20$ $\mathrm{mmol} / \mathrm{L}$ of Tris (pH 8.0), $5 \mathrm{mmol} / \mathrm{L}$ of EDTA, $1 \times$ Denhard's solution, $10 \%$ dextran sulfate, $10 \mathrm{mmol} / \mathrm{L}$ of DDT at $50^{\circ} \mathrm{C}$, hybridization with 500 to $700,000 \mathrm{cpm}$ of sulfur 35-labeled riboprobe was performed overnight. Slides were rinsed and treated with $20 \mu \mathrm{g} / \mathrm{mL}$ of RNase A type IIA (Sigma) for 30 minutes at $37^{\circ} \mathrm{C}$. Three high-stringency washes in $0.1 \times$ SSC (including $0.5 \%$ Tween; Sigma) at $50^{\circ} \mathrm{C}$ for 40 minutes each were followed by dehydration in a graded ethanol series including $0.3 \mathrm{~mol} / \mathrm{L}$ of ammonium acetate. Slides were dipped in NTB2 nuclear emulsion (Kodak, Rochester, $\mathrm{NY}$ ) and exposed in the dark at $4^{\circ} \mathrm{C}$ between 2 and 8 weeks. Slides were counterstained with hematoxylin and eosin, dehydrated, and cover slipped with Histomount (National Diagnostics, Atlanta, GA). Hybridization of replicate tissue sections with sense probes was performed as a control.

\section{Immunohistochemistry}

Specificity and sensitivity of the antibodies against human CD3-positive T cells (rabbit antihuman; A0452; Dako, Carpenteria, CA), ${ }^{18}$ human CD68-positive macrophages (monoclonal mouse antihuman; clone PG-M1; Dako), ${ }^{18}$ human CCR5 (MC5), ${ }^{18,26}$ and DARC $(2 \mathrm{C} 3)^{21}$ have been reported previously for their immunohistochemical use in formalfixed paraffin-embedded tissue. Antigen retrieval was performed on deparaffinized and rehydrated slides by steam cooking in Antigen Unmasking Solution (Vector, Burlingame, CA). Endogenous peroxidase was blocked by incubation with 3\% hydrogen peroxide and biotin using the Avidin/ Biotin Blocking Kit (Vector). The primary antibodies were applied for 1 hour or overnight, diluted in phosphate-buffered saline containing $1 \%$ bovine serum albumin (Sigma). After subsequent washing in phosphate-buffered saline, the tissue was incubated with the biotinylated secondary antibody for 30 minutes in a dilution of 1:500 (goat antirabbit, horse antimouse; Vector). For signal amplification, the ABC-Elite reagent (Vector) was used. 3,3'-Diaminobenzidine with nickel enhancement, resulting in a black product, was used as chromogen. Slides were counterstained with methyl green, dehydrated, and cover slipped.

The interstitial infiltrates of all specimens were scored semiquantitatively as follows: no interstitial infiltration, 0 ; mild, 1; moderate, 2; and severe, 3 . The score reflects the overall amount of positive cells in the tubulointerstitium (including tubular epithelium, peritubular infiltrates, and vascular structures). Glomerular cells positive by immunohistochemistry (CD3, CD68, and CCR5) were classified as follows: no positive cells, 0 ; up to two positive cells per glomerulus, 1; up to four positive cells per glomerulus, 2; and five or more positive cells per glomerulus, 3. The numbers are given as mean scores and SEM.

\section{RESULTS}

Expression of CC Chemokines, CC Chemokine Receptors by RPA, and Their Morphological Correlation

RPA is a sensitive and specific method that allows the quantification of different mRNAs relative to housekeeping genes, but it does not identify the cellular source of expression. Total RNA was extracted from four transplant nephrectomy specimens and a normal part of a tumor nephrectomy specimen for RPA with templates for CC chemokines and CC chemokine receptors (Figs 1 and 2). The morphological features of the specimen in lane A (Figs 1 and 2) are shown in Fig 3. In a normal area of a tumor nephrectomy specimen, we were able to detect mRNA bands for interleukin-8, MCP-1, and RANTES, as well as weaker bands for lymphotactin, IP-10, and MIP- $1 \beta$ by RPA. This correlated with a small number of leukocyte infiltrates in this specimen (Fig 3B).

The transplant nephrectomy specimens were from grafts with acute cellular rejection (lanes C and D, Figs 1 and 2) and acute vascular rejection (lanes B and E, Figs 1 and 2). The amount of RNA of the control, reflected by the housekeeper genes (L32 and GAPDH), was similar to or greater than the amount of RNA of the transplant nephrectomy specimens. During allograft rejection, mRNA bands of lymphotactin (three of four specimens), IP-10 (four of four specimens), RANTES (three of four specimens), MIP- $1 \alpha$ (three of four specimens), and MIP- $1 \beta$ (four of four specimens) were stronger in the transplant nephrectomy specimens than controls. MCP-1 mRNA expression was found in both allografts and controls (Fig 1). This was caused by expression of MCP-1 mRNA at focal sites of cellular infiltrates in the tumor nephrectomy specimens. In these areas, MCP-1 mRNA was expressed by infiltrating cells and tubular epithelium (Fig 3C), but MCP-1 mRNA expression was rare in areas of well-preserved renal tissue.

During allograft rejection, upregulation of CCR5 (three of four specimens) was present by RPA. Figure $3 \mathrm{E}$ and $\mathrm{F}$ shows the high number and morphological distribution of CD3-positive $\mathrm{T}$ cells and CCR5-positive cells in the intersti- 

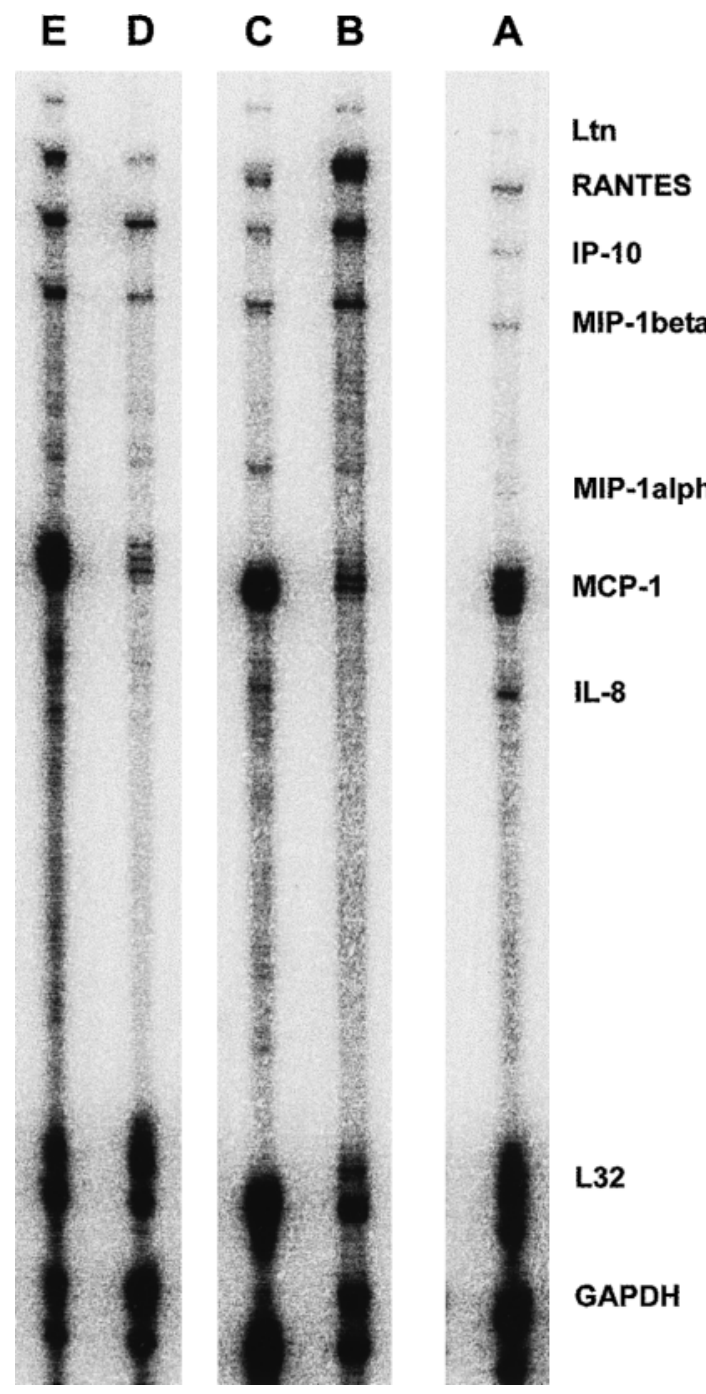

Fig 1. RPA performed with a template for human chemokines. The lanes were loaded with whole RNA extracted from (lane $A$ ) the normal area of a tumor nephrectomy specimen and (lanes B through E) transplant nephrectomy specimens. The transplant nephrectomy specimens were from patients with (lanes $C$ and D) acute cellular rejection and (lanes $B$ and E) acute vascular rejection. Note induction of RANTES, MIP-1 $\beta$, MIP-1 $\alpha$, lymphotactin, and IP-10 mRNA. Abbreviations: Ltn, lymphotactin; IL-8, interleukin-8; GAPDH, glyceraldehyde-3-phosphate dehydrogenase.

tium in the specimen used in lane B. Expression of the chemokine receptor CCR2 (four of four specimens) was also increased during transplant rejection. An increase in CCR2A mRNA was present in two cases, in addition to CCR2B mRNA. Both allografts and controls contained a strong band for CCR1 without further particular induction during allograft rejection (Fig 2).

Weaker bands of CCR4 mRNA were found in all five specimens, with a slight increase in one case with vascular rejection. None of the specimens contained detectable CCR3 and CCR8 mRNA.

\section{Morphological Distribution of Chemokine-Receptor Expression in Normal Areas of Tumor Nephrectomy Specimens}

The renal parenchyma of five tumor nephrectomy specimens was generally well preserved (Fig 3A and D), but all specimens contained small foci of leukocytes (Fig 3B). These infil-

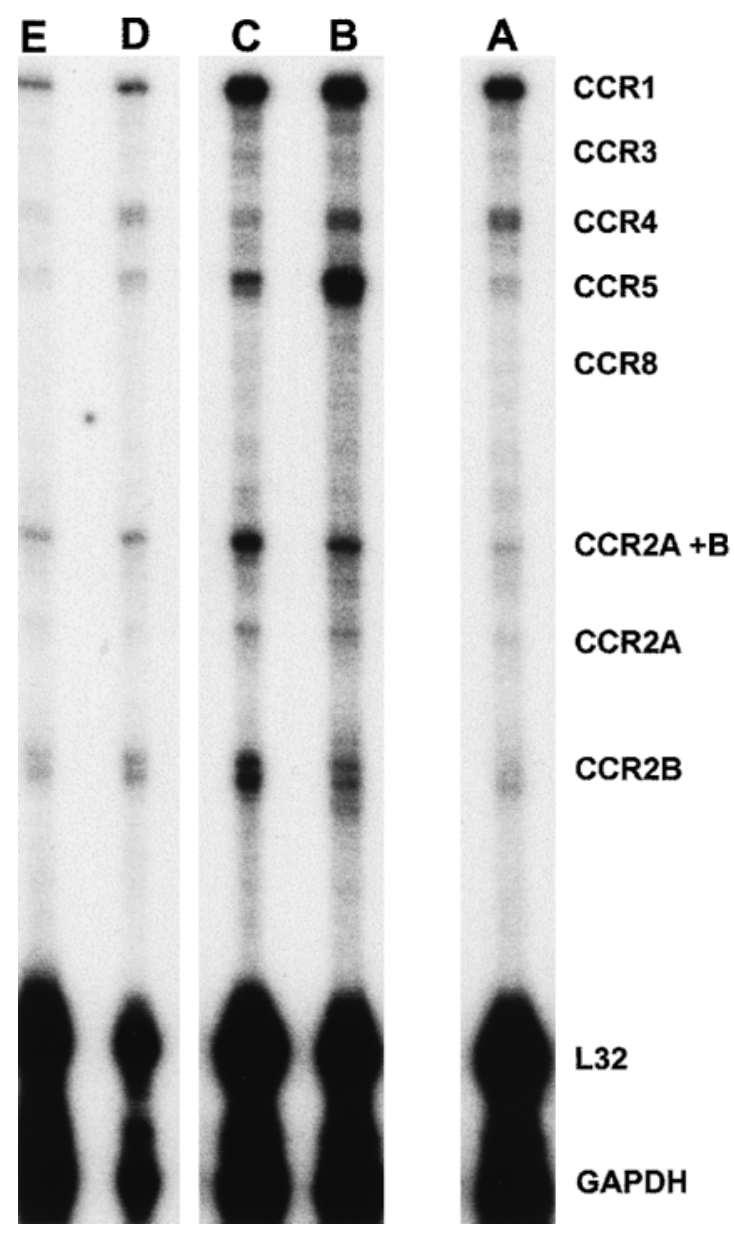

Fig 2. RPA with a template for human chemokine receptors. The lanes were loaded with whole RNA extracted from (lane A) the normal area of a tumor nephrectomy specimen and (lanes B through E) transplant nephrectomy specimens, corresponding to Fig 1. Note strong CCR1 mRNA expression in all specimens. CCR5 and CCR2 mRNA levels are increased during transplant rejection. CCR3 and CCR8 mRNA were not detectable. Abbreviation: GAPDH, glyceraldehyde-3-phosphate dehydrogenase. 

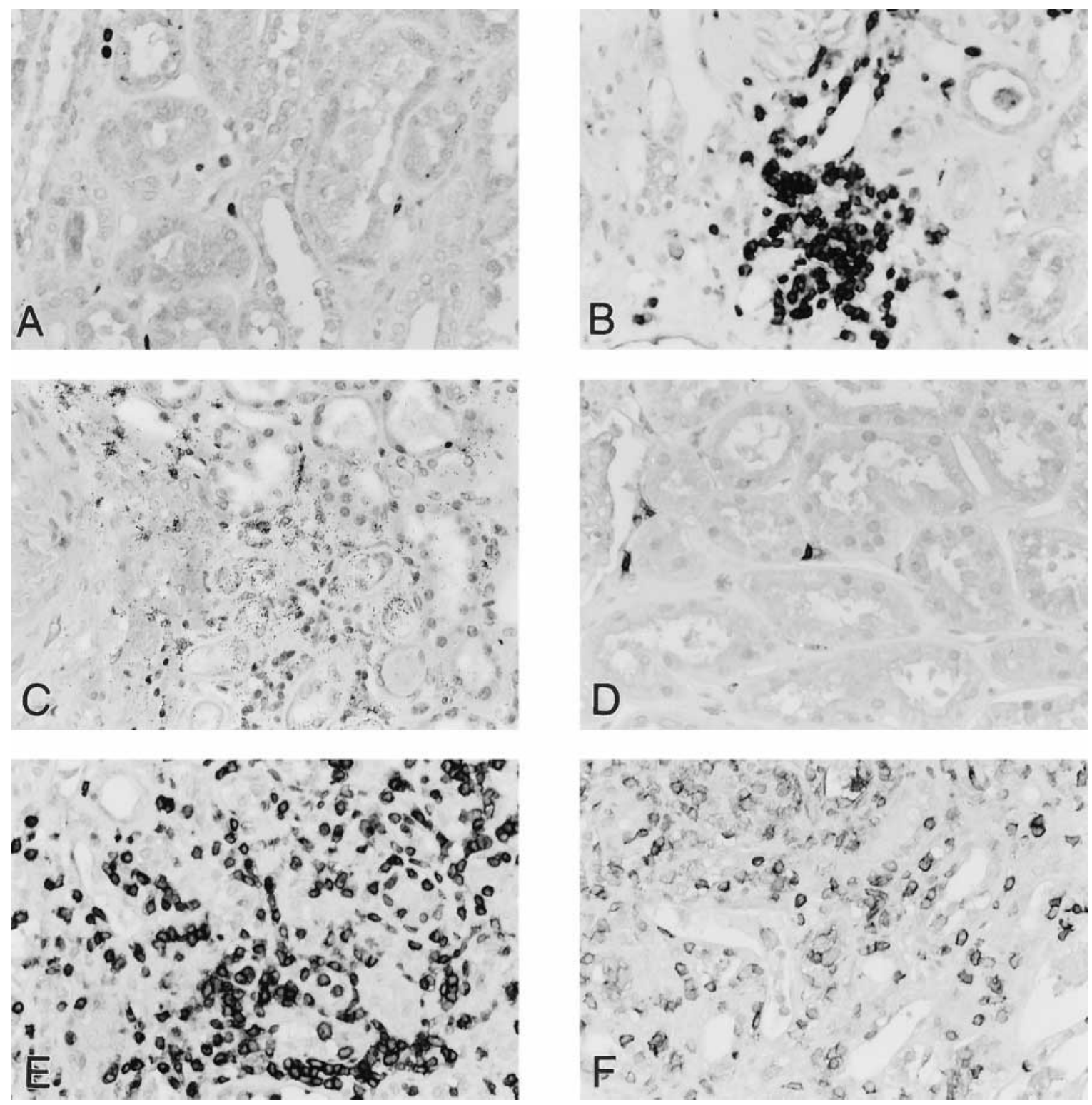

Fig 3. Distribution of CD3-positive T cells, CCR5-positive cells, and MCP-1 expression in tumor and transplant nephrectomy specimens. (A, B, and D) Immunohistochemistry for CD3-positive T cells and CCR5-positive cells in a tumor nephrectomy specimen shows (A) the low number of T cells and (D) CCR5-positive cells in areas of well-preserved tubular interstitium and (B) small focal T-cell infiltrate in a tumor nephrectomy specimen. (C) In situ hybridization using an antisense riboprobe against MCP-1 in a tumor nephrectomy specimen. MCP-1 mRNA is expressed by infiltrating cells and tubular epithelium (compare with lane $A$ in Figs 1 and 2). (E and F) Immunohistochemistry identifies (E) CD3-positive T cells and (F) CCR5-positive cells in a transplant nephrectomy specimen with vascular and cellular rejection. Note the strong diffuse interstitial infiltration by $T$ cells and CCR5-positive cells (compare with lane B in Figs 1 and 2). (Original magnification $\times 400$; signal, [A and B] black color, [C] deposition of silver grains.)

trates were found adjacent to globally sclerosed glomeruli, which are common in aging kidneys, and in areas of mild interstitial fibrosis (Fig 3B). The score for interstitial CD68-positive macrophages in controls was higher $(1.6 \pm 0.2)$ than the score for interstitial CD3-positive $\mathrm{T}$ cells $(1 \pm 0$; Table 1). Glomerular scores did not differ for these cell types. In areas of well-preserved renal tissue, MCP-1 expression was rare, and CXCR4- and CCR5-positive cells were only 
Table 1. Interstitial Scores for Different Histological Parameters in Normal Areas of Tumor Nephrectomy Specimens and Specimens With Acute Cellular and Acute Vascular Rejection

\begin{tabular}{lccc}
\hline Cell Type & Control (tumor nephrectomies) & Cellular Rejection & Vascular Rejection \\
\hline CD3 & $1.0 \pm 0.0(n=5)$ & $2.2 \pm 0.19(n=14)$ & $2.8 \pm 0.11(n=12)$ \\
CD68 & $1.6 \pm 0.24(n=5)$ & $2.3 \pm 0.13(n=14)$ & $2.8 \pm 0.13(n=12)$ \\
CXCR4 & $1.3 \pm 0.25(n=4)$ & $2.3 \pm 0.15(n=10)$ & $2.5 \pm 0.16(n=11)$ \\
CCR5 & $1.0 \pm 0.0(n=5)$ & $2.0 \pm 0.2(n=14)$ & $2.4 \pm 0.2(n=12)$ \\
CCR2 & $1.0 \pm 0.0(n=3)$ & $2.0 \pm 0.26(n=10)$ & $2.0 \pm 0.21(n=10)$ \\
MCP-1 & $2.0 \pm 0.4(n=5)$ & $1.8 \pm 0.2(n=12)$ & $2.6 \pm 0.1(n=12)$ \\
DARC & $1.2 \pm 0.2(n=5)$ & $2.1 \pm 0.16(n=14)$ & $2.6 \pm 0.15(n=12)$ \\
\hline
\end{tabular}

NOTE. Values expressed as mean \pm SEM. See Methods for details.

occasionally seen within glomerular capillaries or the interstitium (Fig 3D). DARC reactivity was found on a low number of interstitial capillaries and veins in well-preserved renal tissue (Fig 4A). In areas of interstitial infiltrates, clusters of DARC-positive vessels were found.

\section{Morphological Distribution of \\ Chemokine-Receptor Expression During Renal Allograft Rejection}

Leukocytic allograft infiltrates were separated into four sites: (1) diffuse interstitial infiltrates, identified as accumulation of leukocytes between tubules and infiltrating the tubular epithelium (Fig 5); (2) distinct nodular aggregates, which sometimes formed follicles (Fig 6); (3) involved arteries, showing vascular rejection (Fig 7); and (4) glomeruli. Table 2 lists a descriptive summary of morphological data.

The diffuse infiltrates between tubules contained a similar number of CD3-positive T cells

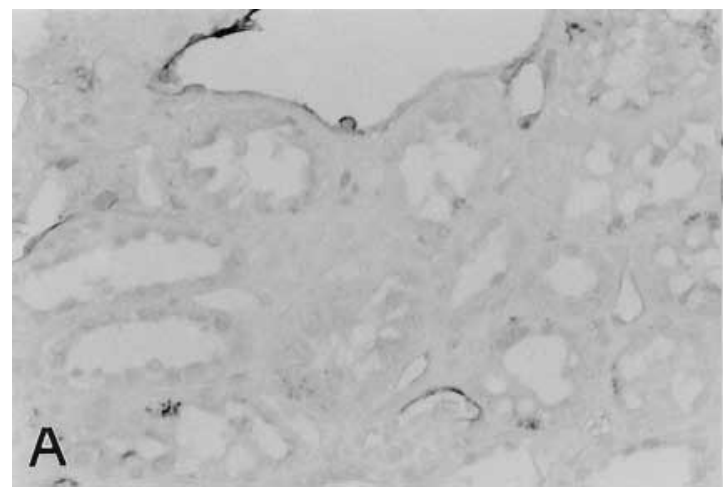

and CD68-positive macrophages in morphologically similar patterns of distribution (Fig 5A and B). CD3-positive T cells formed a population of small round cells without processes, whereas CD68-positive cells were larger, with a granular cytoplasmic staining, and sometimes showed processes. There was a large amount of CD68positive material not adjacent to nuclei, ie, crosssections of cell processes. Both cell types infiltrated the tubular epithelium. Within tubular lumina, round CD68-positive cells could commonly be detected, whereas intraluminal CD3positive $\mathrm{T}$ cells were rare. CCR5-positive cells formed a major part of the diffuse interstitial infiltrates. These cells, most of them small and round without processes, commonly infiltrated the tubular epithelium but were rare within the tubular lumina. CXCR4-positive cells showed a distribution pattern indistinguishable from that of CCR5-positive cells in diffuse interstitial infiltrates, but their relative number was higher (Fig

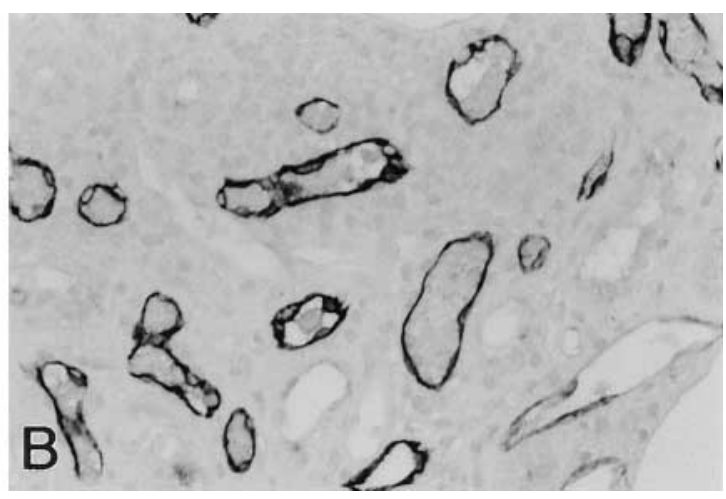

Fig 4. Immunohistochemistry for DARC in a normal area of (A) a tumor nephrectomy specimen and (B) a transplant nephrectomy specimen. During acute allograft rejection, a high number of DARC-positive capillaries can be detected in the $(B)$ inflamed interstitium compared with $(A)$ the tumor nephrectomy specimen. (Original magnification $\times 400$.) 

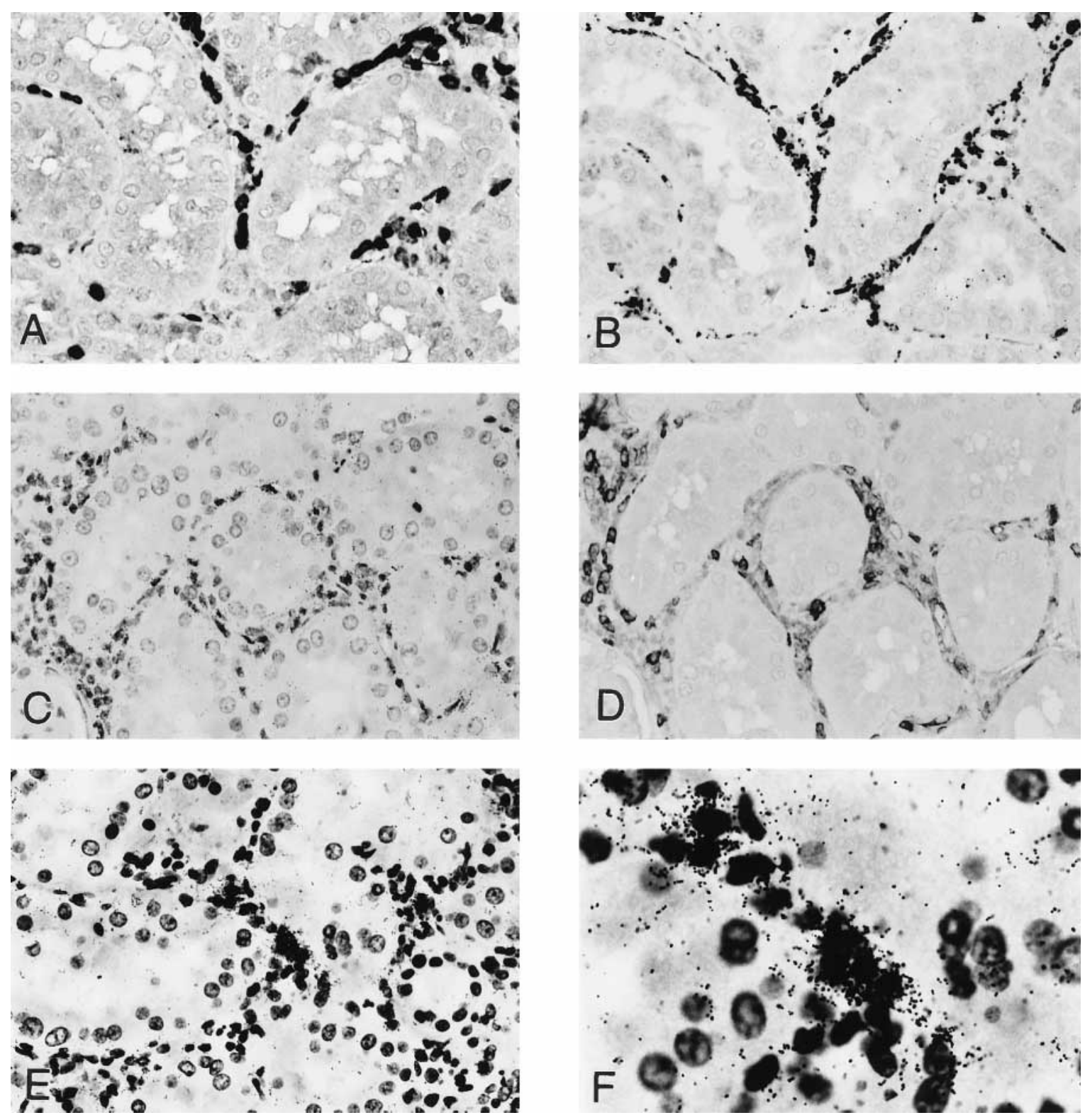

Fig 5. Distribution of T cells, macrophages, and CCRs in diffuse infiltrates. (A and B) Immunohistochemistry for (A) CD3-positive T cells and (B) CD68-positive macrophages in serial sections of a transplant nephrectomy specimen shows the corresponding distribution of both types of infiltrating cells. (C and D) In situ hybridization using (C) an antisense riboprobe for CXCR4 and (D) immunohistochemistry for CCR5-positive cells on serial sections of a transplant nephrectomy specimen show the corresponding distribution of cells expressing these receptors in diffuse infiltrates. (E and F) In situ hybridization using an antisense riboprobe for CCR2B. (Original magnification $[A-E] \times 400$ and $[F] \times 1,000$.)

5C and D). CCR2B mRNA was expressed by infiltrating leukocytes, but the number was lower relative to the number of CCR5- and CXCR4positive cells. No CCR2B mRNA expression by tubular epithelial cells was detected (Fig 5E and F). MCP-1 mRNA was expressed by intrinsic renal cells (tubular epithelium and parietal epithelium), as well as by infiltrating cells. DARC expression was found on the endothelium of capillaries and veins. Glomerular endothelium was negative for DARC. The number of DARCpositive peritubular capillaries and veins in- 

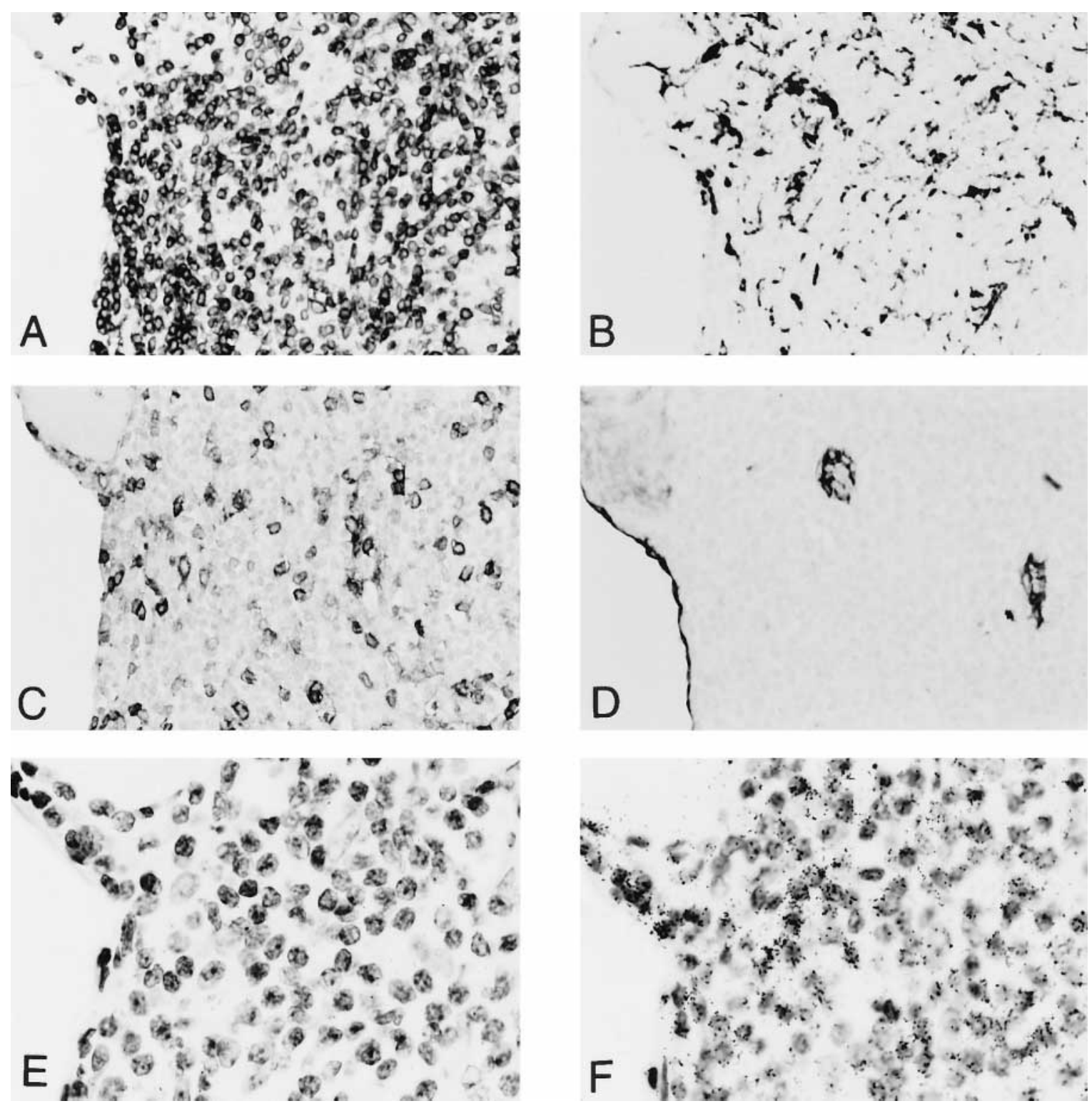

Fig 6. Distribution of cell types in nodular infiltrates. (A and B) Immunohistochemistry for (A) CD3-positive T cells and (B) CD68-positive macrophages in serial sections of a transplant nephrectomy specimen. The nodular infiltrate is located adjacent to (left) a large vein and mainly consists of CD3-positive T cells. (C) Immunohistochemistry for CCR5 on a consecutive section of the specimen shown in A. CCR5-positive cells form a relatively small part of the infiltrate. (D) Immunohistochemistry for DARC on a consecutive section of the specimen shown in (A). The adjacent large vein is covered by a DARC-positive flat endothelium, whereas two capillaries within the infiltrate show a DARC-positive high endothelium. ( $E$ and $F$ ) In situ hybridization using (E) a sense and (F) an antisense riboprobe for CXCR4 showing (E) the low number of unspecific deposited silver grains in the control. A high number of silver grains are deposited over the largest part of the infiltrating cells, resembling an infiltrate mainly consisting of CXCR4-positive cells. (Original magnification $[A-D] \times 400$ and $[E$ and $F] \times 1,000$.)

creased in areas of diffuse interstitial infiltrates compared with normal areas of tumor nephrectomy specimens (Fig 4B).

Some rejecting allografts focally contained nodular aggregates of infiltrating leukocytes, mainly composed of CD3-positive T cells (Fig 6A). Within these aggregates, a smaller number of macrophages was dispersed between the $\mathrm{T}$ 

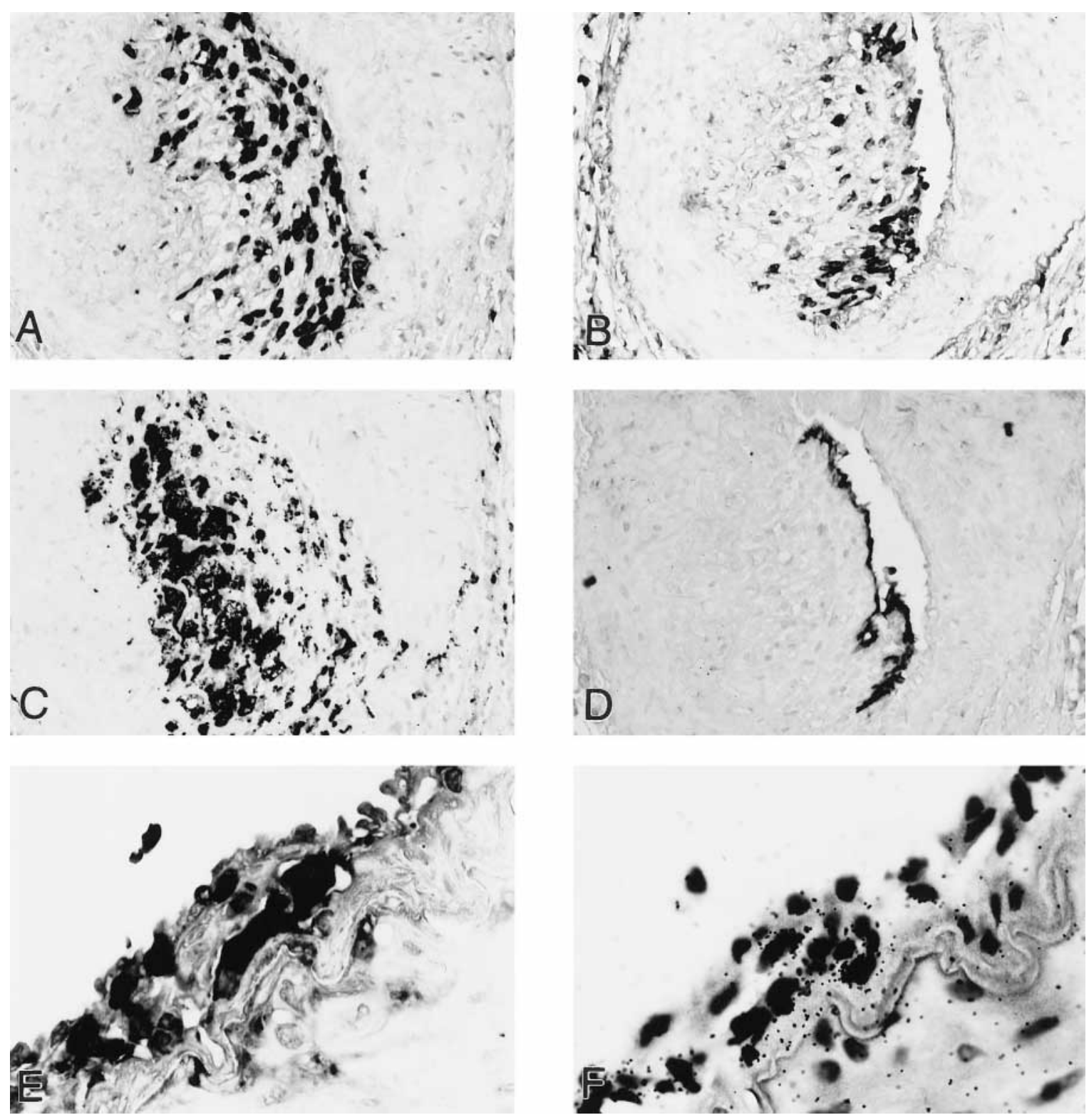

Fig 7. Cellular infiltration during vascular rejection. (A through D) Immunohistochemistry for (A) CD3-positive T cells, (B) CCR5-positive cells, (C) CD68-positive macrophages, and (D) DARC on consecutive sections of a transplant biopsy specimen with vascular rejection. CD3-positive cells are located in the superficial subendothelial area. CCR5-positive cells follow the same distribution, but the number is less than the number of $T$ cells. CD68-positive macrophages form a layer below the CD3-positive T cells. At this site, CCR5-positive cells were rare. (D) The rare DARC expression on arterial endothelium. Note that the lumen of the artery is completely occluded in the sections stained for CD68 and CD3. (E and F) Immunohistochemistry for (E) CCR5 and in situ hybridization using an antisense riboprobe for CXCR4 in serial sections of a transplant nephrectomy specimen with vascular rejection. CCR5- and CXCR4-positive cells can be detected at similar sites infiltrating the subendothelial intima. (Original magnification $[A-D] \times 400$ and $[E$ and $F] \times 1,000$.)

cells (Fig 6B). CCR5-positive cells comprised only a small proportion of the cells within these aggregates (Fig 6C). Conversely, CXCR4 mRNA was widely expressed by cells within these aggre- gates, indicating that most of these $\mathrm{T}$ cells were CXCR4 positive (Fig 6F). Cells expressing CCR2B and MCP-1 mRNA showed a distribution similar to that of CD68-positive macro- 
Table 2. Descriptive Summary of Morphological Data

\begin{tabular}{|c|c|c|c|c|c|}
\hline \multirow[b]{2}{*}{ Antigen } & \multirow[b]{2}{*}{ Expressing Cell Type } & \multicolumn{4}{|c|}{ Renal Compartment } \\
\hline & & Interstitic & Infiltrates & Arteries & Glomeruli \\
\hline \multicolumn{6}{|c|}{$\begin{array}{l}\text { Controls (tumor nephrectomy } \\
\text { specimens) }\end{array}$} \\
\hline CD3 & T cells & \multicolumn{2}{|c|}{+ focal } & - & + \\
\hline CD68 & Macrophages & \multicolumn{2}{|c|}{++ focal } & - & + \\
\hline CXCR4 & Inf leukocytes & \multicolumn{2}{|c|}{+ focal } & - & + \\
\hline CCR5 & Inf leukocytes & \multicolumn{2}{|c|}{+ focal } & - & + \\
\hline CCR2 & Inf leukocytes & \multicolumn{2}{|c|}{+ focal } & - & + \\
\hline MCP-1 & Inf leukocytes tubular epithelium & \multicolumn{2}{|c|}{+ focal } & - & + \\
\hline \multirow[t]{2}{*}{ DARC } & Capillary, venous endothelium & \multicolumn{2}{|c|}{+} & - & - \\
\hline & & Diffuse & Nodular & & \\
\hline \multicolumn{6}{|c|}{ Cellular rejection } \\
\hline CD3 & T cells & +++ & +++ & - & + \\
\hline CD68 & Macrophages & +++ & + & - & + \\
\hline CXCR4 & Inf leukocytes & +++ & +++ & - & + \\
\hline CCR5 & Inf leukocytes & ++ & + & - & + \\
\hline CCR2 & Inf leukocytes & + & + & - & + \\
\hline MCP-1 & $\begin{array}{l}\text { Inf leukocytes tubular epithelium, } \\
\text { parietal epithelium }\end{array}$ & ++ & + & - & + \\
\hline DARC & Capillary, venous endothelium & $\begin{array}{c}++ \\
\text { Diffuse }\end{array}$ & $\begin{array}{c}++ \\
\text { Nodular }\end{array}$ & - & - \\
\hline \multicolumn{6}{|c|}{ Vascular rejection } \\
\hline CD3 & T cells & +++ & +++ & +++ & + \\
\hline CD68 & Macrophages & +++ & + & +++ & ++ \\
\hline CXCR4 & Inf leukocytes & +++ & +++ & +++ & + \\
\hline CCR5 & Inf leukocytes & ++ & + & ++ & + \\
\hline CCR2 & Inf leukocytes & + & + & + & + \\
\hline MCP-1 & $\begin{array}{l}\text { Inf leukocytes tubular epithelium, } \\
\text { parietal epithelium }\end{array}$ & ++ & + & + & + \\
\hline DARC & Capillary, venous, arterial endothelium & ++ & ++ & + rare & - \\
\hline
\end{tabular}

Abbreviation: Inf, infiltrating.

phages. In nodular aggregates, the number of CCR2B-positive cells was greater than the number of CCR5-positive cells. Within aggregates, DARC-positive capillaries were commonly lined by a high endothelium (Fig 6D). The adjacent larger veins were usually DARC positive and lined by a flat endothelium.

During vascular rejection, CD3-positive T cells and CD68-positive macrophages were found in the subendothelial intima of arteries and in lower numbers throughout the vessel wall (Fig 7A and C). Usually, CD68-positive macrophages slightly outnumbered CD3-positive T cells. The number and distribution of CCR5-positive cells mirrored the number of T cells (Fig 7A and B). CXCR4positive cells were found in a higher number than CCR5-positive cells (Fig 7F). The number of CCR2B-positive cells was lower, but they formed a significant part of the infiltrating cells in arte- rial walls. Expression of MCP-1 mRNA by arterial endothelium was rarely found, but was common in infiltrating cells in the arterial wall. DARC expression was usually absent on arterial endothelium; only 2 of 12 artery specimens with vascular rejection showed expression by arterial endothelium. One of these arteries was completely occluded on consecutive sections (Fig 7C and D).

Macrophages outnumbered $\mathrm{T}$ cells in glomeruli. The cellular score for glomerular macrophages was slightly higher in vascular rejection $(2.5 \pm 0.21)$ compared with cellular rejection (1.9 \pm 0.26$)$ and tumor nephrectomy specimens $(1.8 \pm 0.32)$. Numbers of glomerular T cells and CCR5-positive cells were similar in all three groups. CXCR4-positive cells were more common in glomeruli than CCR5-positive cells. MCP-1 mRNA expression by cells in the glomer- 
ular tuft and occasionally on parietal epithelial cells was present. No DARC expression on glomerular endothelium was detected.

The scores for CD3-positive T cells, CD68positive macrophages, CXCR4, CCR5, CCR2B, and DARC were increased in specimens with acute transplant rejection (Table 1).

\section{DISCUSSION}

Several studies indicate a role for MCP-1 and its receptor, CCR2, during tubular injury in renal allograft rejection (reviewed in Segerer et al ${ }^{14}$ ), but no data are available about the morphological distribution of CCR2B in human allografts. We showed an induction of CCR2B and, in some cases, CCR2A during allograft rejection by RPA. This appears to be caused by an increased number of CCR2B mRNA-expressing infiltrating leukocytes, shown by in situ hybridization. The number of CCR2B-expressing cells detected by this method is less than the number of CCR5 protein-expressing cells and CXCR4 mRNAexpressing cells. The scattered distribution of CCR2B-expressing cells, especially in nodular aggregates of infiltrating cells, corresponding to the distribution of CD68-expressing cells, indicates that these cells are mainly macrophages. We found no evidence of CCR2B expression by renal parenchymal cells. Sites of MCP-1 expression corresponded to the sites where CCR2Bpositive cells were localized.

According to their profile of secreted cytokines, Th cells are divided into Th1 and Th2 cells. ${ }^{27}$ These T-cell subsets preferentially express certain cytokines and chemokine receptors. CXCR3, a receptor for IP-10, and CCR5, a receptor for RANTES, MIP- $1 \alpha$, and MIP- $1 \beta$, are mainly expressed by Th1 cells. Th2 cells mainly express CCR3, CCR4, and CCR8. ${ }^{28-32}$ The pattern of chemokine and chemokine-receptor activation identified by RPA in transplant nephrectomy specimens, with induction of IP-10, the CCR5 ligands, and CCR5 mRNA in combination with an absence of CCR3 and CCR8, is consistent with a Th1-type immune reaction within renal allografts. This provides new evidence in support of the importance of a Th1-type immune response during human renal allograft rejection, previously shown by the expression pattern of cytokines in isolated T-cell clones and by poly- merase chain reaction in transplant biopsy specimens. ${ }^{12,13,33}$

During renal allograft rejection, the number of infiltrating CD3-positive T cells and CD68positive macrophages increases, consistent with previous studies. ${ }^{6,7,34} \mathrm{CD} 3$-positive $\mathrm{T}$ cells were diffusely distributed in the renal interstitium and at times formed nodular aggregates, typically localized adjacent to large veins. The increased number of $\mathrm{T}$ cells infiltrating the renal allograft has been reported to be caused by both CD4- and CD8-positive subpopulations,,${ }^{6,734}$ and a correlation between the distribution pattern and T-cell subset has been described ${ }^{6,34,35}$ (ie, areas of T-cell aggregates consist mainly of CD4-positive $\mathrm{T}$ cells, whereas CD8-positive T cells diffusely infiltrate the interstitium). CD3-positive $\mathrm{T}$ cells and macrophages are the main cell types infiltrating the subendothelial space during vascular rejection. ${ }^{3}$ The presence of CCR5-positive cells during renal allograft rejection, both at the mRNA and protein levels, has been previously described by our groups. ${ }^{18,20}$ In concordance with these previous studies, we found upregulation of CCR5 mRNA by RPA. We found that CCR5-positive cells are differentially distributed in allograft rejection. CCR5-positive cells are a prominent subpopulation in diffuse leukocytic infiltrates, but comprise only a small number of the cells that form localized nodular aggregates of infiltrating cells. The distribution of T-cell subsets previously described suggests that the high number of CCR5-positive cells in diffuse infiltrates is mainly caused by expression of this receptor by CD8positive T cells.

Increased expression of the CC chemokines, RANTES, MIP- $1 \alpha$, MIP- $1 \beta$, and MCP-1, has been shown during renal transplant rejection by infiltrating cells, tubular epithelial cells, and endothelium. ${ }^{36-39}$ It is striking that cells bearing the CCR5 receptor for these chemokines in tubulointerstitial infiltrates, tubulitis, and endothelialitis correspond to the distribution of the appropriate ligands. ${ }^{18,36}$ It has been shown by others that MCP-1 expression during acute renal transplant rejection correlates with the number of infiltrating macrophages ${ }^{40}$ Furthermore, in that study, elevated urinary MCP-1 excretion during rejection episodes decreased after successful treatment. ${ }^{40}$ By RPA, we confirmed the upregulation 
of RANTES, MIP- $1 \alpha$, and MIP- $1 \beta$. We saw no significant induction of MCP-1 mRNA during transplant rejection, which may have been caused by a relatively high expression of MCP-1 in control tissue.

The percentage of CCR5-positive cells in tubulointerstitial infiltrates was less than that of CXCR4-positive cells in this study. We previously described the high number of CXCR4positive cells infiltrating transplant nephrectomy specimens. ${ }^{19}$ Neointimal T cells, but not smooth muscle cells, expressed this receptor. Of the chemokine receptors studied, CXCR4 was the most widely expressed during transplant rejection. ${ }^{19}$ In diffuse interstitial infiltrates and at sites of vascular rejection, there is a very similar distribution of CCR5-positive and CXCR4-positive cells. This might have two explanations: either a similar source of the ligands or a population of double-positive cells. We were not able to exclude double-positive cells because our attempts to combine in situ hybridization with immunohistochemistry for CCR5 have been unsuccessful. Currently, the expression of stromal-derived growth factor-1 (SDF-1), the only known ligand for CXCR4, during renal diseases is unknown. The high percentage of CXCR4-positive cells during transplant rejection is surprising because in vitro data indicate that CXCR4 is a main receptor on naïve $\mathrm{T}$ cells $\left(\mathrm{CD} 45 \mathrm{RA}^{+}\right)$, whereas CCR5 is selectively expressed on memory $\mathrm{T}$ cells $\left(\mathrm{CD} 45 \mathrm{RO}^{+}\right){ }^{41,42}$ Further studies are needed to evaluate the expression of SDF-1 or other potential but still unidentified ligands of CXCR4 and the potential functional role of CXCR4 in transplantation. We speculate that the high number of CXCR4-positive cells and the low number of CCR5-positive leukocytes in nodular aggregates (ie, follicle-like structures) containing vessels with high endothelium could indicate a site of immune-cell recirculation and a source of naïve T cells.

DARC binds several CC and CXC chemokines, including RANTES and MCP-1. In the kidney, DARC is expressed on interstitial vessels ranging from the size of capillaries to larger veins and might be involved in the attraction and transmigration of leukocytes into the allograft. ${ }^{43}$ We did not detect DARC expression on glomerular endothelium, which is in contrast to a study of cryosection using a polyclonal antibody. ${ }^{44} \mathrm{We}$ have previously described the upregulation of DARC during cell-mediated renal injury. ${ }^{21}$ The increased number of DARC-positive interstitial vessels, peritubular capillaries, and veins during allograft rejection was confirmed by this study. There is a strong association between sites of infiltration and DARC-positive vessels during renal inflammation. DARC-positive vessels occasionally showed the morphological appearance of high endothelial venules, as they occur in tonsils and lymph nodes, especially in follicular infiltrates. During vascular rejection, the arterial endothelium can become DARC positive. This site of DARC expression has not yet been described and appears to be rare because it was not detected in our previous study and was detected in only two specimens in this series. ${ }^{21}$

Current data lead to several questions for future studies. Two chemokines likely involved in the attraction of T cells, ie, IP-10 and lymphotactin, were upregulated during allograft rejection. Their distribution and the distribution of the corresponding receptors are currently unknown. Another intriguing result is the high expression of CCR1 in both normal kidney and rejecting renal allografts. CCR1 can be induced on mesangial cells stimulated with interferon- $\gamma$ in vitro, ${ }^{45}$ and a recent study described increased T-cell and macrophage infiltration caused by an enhanced Th1 response in CCR1-deficient mice during nephrotoxic serum nephritis. ${ }^{46}$ The distribution of CCR1 in normal and allograft kidneys is currently unknown, but the predicted counterregulatory role of this receptor might be of major impact for therapeutic studies and therefore merits further evaluation.

\section{REFERENCES}

1. Ishikawa A, Flechner SM, Goldfarb DA, Myles JL, Modlin CS, Boparai N, Papajcik D, Mastroianni B, Novick AC: Quantitative assessment of the first acute rejection as a predictor of renal transplant outcome. Transplantation 68 : 1318-1324, 1999

2. Flechner SM, Modlin CS, Serrano DP, Goldfarb DA, Papajcik D, Mastroianni B, Goormastic M, Novick AC: Determinants of chronic renal allograft rejection in cyclosporine-treated recipients. Transplantation 62:1235-1241, 1996

3. Alpers CE, Gordon D, Gown AM: Immunophenotype of vascular rejection in renal transplants. Mod Pathol 3:198203, 1990

4. Pardo-Mindan FJ, Salinas-Madrigal L, Idoate M, Ga- 
rola R, Sola I, French M: Pathology of renal transplantation. Semin Diagn Pathol 9:185-199, 1992

5. Platt JL, LeBien TW, Michael AF: Interstitial mononuclear cell populations in renal graft rejection. Identification by monoclonal antibodies in tissue sections. J Exp Med 155:17-30, 1982

6. Hall BM, Bishop GA, Farnsworth A, Duggin GG, Horvath JS, Sheil AG, Tiller DJ: Identification of the cellular subpopulations infiltrating rejecting cadaver renal allografts. Preponderance of the T4 subset of T cells. Transplantation 37:564-570, 1984

7. Grimm PC, McKenna R, Nickerson P, Russell ME, Gough J, Gospodarek E, Liu B, Jeffery J, Rush DN: Clinical rejection is distinguished from subclinical rejection by increased infiltration by a population of activated macrophages. J Am Soc Nephrol 10:1582-1589, 1999

8. Mosmann TR, Cherwinski H, Bond MW, Giedlin MA, Coffman RL: Two types of murine helper T cell clone. I. Definition according to profiles of lymphokine activities and secreted proteins. J Immunol 136:2348-2357, 1986

9. Cher DJ, Mosmann TR: Two types of murine helper T cell clone. II. Delayed-type hypersensitivity is mediated by TH1 clones. J Immunol 138:3688-3694, 1987

10. Sallusto F, Lanzavecchia A, Mackay CR: Chemokines and chemokine receptors in T-cell priming and Th1/ Th2-mediated responses. Immunol Today 19:568-574, 1998

11. Syrbe U, Siveke J, Hamann A: Th1/Th2 subsets: Distinct differences in homing and chemokine receptor expression? Springer Semin Immunopathol 21:263-285, 1999

12. Ode-Hakim S, Docke WD, Kern F, Emmrich F, Volk HD, Reinke P: Delayed-type hypersensitivity-like mechanisms dominate late acute rejection episodes in renal allograft recipients. Transplantation 61:1233-1240, 1996

13. D'Elios MM, Josien R, Manghetti M, Amedei A, de Carli M, Cuturi MC, Blancho G, Buzelin F, del Prete G, Soulillou JP: Predominant Th1 cell infiltration in acute rejection episodes of human kidney grafts. Kidney Int 51: 1876-1884, 1997

14. Segerer S, Nelson PJ, Schlondorff D: Chemokines, chemokine receptors, and renal disease: From basic science to pathophysiologic and therapeutic studies. J Am Soc Nephrol 11:152-176, 2000

15. Baggiolini M: Chemokines and leukocyte traffic. Nature 392:565-568, 1998

16. Luster AD: Chemokines-Chemotactic cytokines that mediate inflammation. N Engl J Med 338:436-445, 1998

17. Ward SG, Westwick J: Chemokines: Understanding their role in T-lymphocyte biology. Biochem J 333:457-470, 1998

18. Segerer S, Mack M, Regele H, Kerjaschki D, Schlondorff D: Expression of the C-C chemokine receptor 5 in human kidney diseases. Kidney Int 56:52-64, 1999

19. Eitner F, Cui Y, Hudkins KL, Alpers CE: Chemokine receptor (CXCR4) mRNA-expressing leukocytes are increased in human renal allograft rejection. Transplantation 66:1551-1557, 1998

20. Eitner F, Cui Y, Hudkins KL, Anderson DM, Schmidt A, Morton WR, Alpers CE: Chemokine receptor (CCR5) expression in human kidneys and in the HIV infected macaque. Kidney Int 54:1945-1954, 1998

21. Segerer S, Regele H, Mack M, Kain R, Cartron JP,
Colin Y, Kerjaschki D, Schlondorff D: The Duffy antigen for chemokines is up-regulated during acute renal transplant rejection and crescentic glomerulonephritis. Kidney Int 58: 1546-1556, 2000

22. Isik FF, Rand RP, Gruss JS, Benjamin D, Alpers CE: Monocyte chemoattractant protein-1 mRNA expression in hemangiomas and vascular malformations. J Surg Res 61:7176, 1996

23. Segerer S, Cui Y, Hudkins KL, Goodpaster T, Eitner F, Mack M, Schlondorff D, Alpers CE: Expression of the chemokine monocyte chemoattractant protein-1 and its receptor chemokine receptor 2 in human crescentic glomerulonephritis. J Am Soc Nephrol 11:2231-2242, 2000

24. Charo IF, Myers SJ, Herman A, Franci C, Connolly AJ, Coughlin SR: Molecular cloning and functional expression of two monocyte chemoattractant protein 1 receptors reveals alternative splicing of the carboxyl-terminal tails. Proc Natl Acad Sci U S A 91:2752-2756, 1994

25. Deng H, Liu R, Ellmeier W, Choe S, Unutmaz D, Burkhart M, Di Marzio P, Marmon S, Sutton RE, Hill CM, Davis CB, Peiper SC, Schall TJ, Littman DR, Landau NR: Identification of a major co-receptor for primary isolates of HIV-1. Nature 381:661-666, 1996

26. Eitner F, Cui Y, Hudkins KL, Stokes MB, Segerer S, Mack M, Lewis PL, Abraham AA, Schlondorff D, Gallo G, Kimmel PL, Alpers CE: Chemokine receptor CCR5 and CXCR4 Expression in HIV-associated kidney disease. J Am Soc Nephrol 11:856-867, 2000

27. Abbas AK, Murphy KM, Sher A: Functional diversity of helper T lymphocytes. Nature 383:787-793, 1996

28. Sallusto F, Mackay CR, Lanzavecchia A: Selective expression of the eotaxin receptor CCR3 by human T helper 2 cells. Science 277:2005-2007, 1997

29. Gerber BO, Zanni MP, Uguccioni M, Loetscher M, Mackay CR, Pichler WJ, Yawalkar N, Baggiolini M, Moser B: Functional expression of the eotaxin receptor CCR3 in T lymphocytes co-localizing with eosinophils. Curr Biol 7:836843,1997

30. Bonecchi R, Bianchi G, Bordignon PP, D'Ambrosio D, Lang R, Borsatti A, Sozzani S, Allavena P, Gray PA, Mantovani A, Sinigaglia F: Differential expression of chemokine receptors and chemotactic responsiveness of type $1 \mathrm{~T}$ helper cells (Th1s) and Th2s. J Exp Med 187:129-134, 1998

31. Siveke JT, Hamann A: T helper 1 and T helper 2 cells respond differentially to chemokines. J Immunol 160:550554,1998

32. Zingoni A, Soto H, Hedrick JA, Stoppacciaro A, Storlazzi CT, Sinigaglia F, D'Ambrosio D, O'Garra A, Robinson D, Rocchi M, Santoni A, Zlotnik A, Napolitano M: The chemokine receptor CCR8 is preferentially expressed in $\mathrm{Th} 2$ but not Th1 cells. J Immunol 161:547-551, 1998

33. Oliveira G, Xavier P, Murphy B, Neto S, Mendes A, Sayegh MH, Guerra LE: Cytokine analysis of human renal allograft aspiration biopsy cultures supernatants predicts acute rejection. Nephrol Dial Transplant 13:417-422, 1998

34. Ibrahim S, Dawson DV, Sanfilippo F: Predominant infiltration of rejecting human renal allografts with $\mathrm{T}$ cells expressing CD8 and CD45RO. Transplantation 59:724-728, 1995

35. Kolbeck PC, Tatum AH, Sanfilippo F: Relationships among the histologic pattern, intensity, and phenotypes of $\mathrm{T}$ 
cells infiltrating renal allografts. Transplantation 38:709713, 1984

36. Pattison J, Nelson PJ, Huie P, von Leuttichau I, Farshid G, Sibley RK, Krensky AM: RANTES chemokine expression in cell-mediated transplant rejection of the kidney. Lancet 343:209-211, 1994

37. Robertson H, Wheeler J, Morley AR, Booth TA, Talbot D, Kirby JA: Beta-chemokine expression and distribution in paraffin-embedded transplant renal biopsy sections: Analysis by scanning laser confocal microscopy. Histochem Cell Biol 110:207-213, 1998

38. Robertson H, Morley AR, Talbot D, Callanan K, Kirby JA: Renal allograft rejection: Beta-chemokine involvement in the development of tubulitis. Transplantation 69:684687,2000

39. Strehlau J, Pavlakis M, Lipman M, Shapiro M, Vasconcellos L, Harmon W, Strom TB: Quantitative detection of immune activation transcripts as a diagnostic tool in kidney transplantation. Proc Natl Acad Sci U S A 94:695700, 1997

40. Grandaliano G, Gesualdo L, Ranieri E, Monno R, Stallone G, Schena FP: Monocyte chemotactic peptide-1 expression and monocyte infiltration in acute renal transplant rejection. Transplantation 63:414-420, 1997

41. Rabin RL, Park MK, Liao F, Swofford R, Stephany $\mathrm{D}$, Farber JM: Chemokine receptor responses on T cells are achieved through regulation of both receptor expression and signaling. J Immunol 162:3840-3850, 1999

42. Sallusto F, Lenig D, Mackay CR, Lanzavecchia A: Flexible programs of chemokine receptor expression on human polarized T helper 1 and 2 lymphocytes. J Exp Med 187:875-883, 1998

43. Hadley TJ, Lu ZH, Wasniowska K, Martin AW, Peiper SC, Hesselgesser J, Horuk R: Postcapillary venule endothelial cells in kidney express a multispecific chemokine receptor that is structurally and functionally identical to the erythroid isoform, which is the Duffy blood group antigen. J Clin Invest 94:985-991, 1994

44. Chaudhuri A, Nielsen S, Elkjaer ML, Zbrzezna V, Fang F, Pogo AO: Detection of Duffy antigen in the plasma membranes and caveolae of vascular endothelial and epithelial cells of nonerythroid organs. Blood 89:701-712, 1997

45. Banas B, Luckow B, Moller M, Klier C, Nelson PJ, Schadde E, Brigl M, Halevy D, Holthofer H, Reinhart B, Schlondorff D: Chemokine and chemokine receptor expression in a novel human mesangial cell line. J Am Soc Nephrol 10:2314-2322, 1999

46. Topham PS, Csizmadia V, Soler D, Hines D, Gerard CJ, Salant DJ, Hancock WW: Lack of chemokine receptor CCR1 enhances Th1 responses and glomerular injury during nephrotoxic nephritis. J Clin Invest 104:1549-1557, 1999 